\title{
ANALISIS KEPUASAN PENGUNJUNG TERHADAP SARANA TRANSPORTASI PULAU PUTRI KABUPATEN BANGKA
}

\section{ANALYSIS OF VISITOR SATISFACTION ON TRANSPORTATION FACILITIES IN PUTRI ISLAND, BANGKA REGENCY}

\author{
Egy Tiansyah*, Andi Gustomi, Sudirman Adibrata \\ Program Studi Manajemen Sumberdaya Perairan, Fakultas Pertanian Perikanan dan Biologi, \\ Universitas Bangka Belitung \\ Kampus Terpadu UBB, Gedung Teladan, Bangka, Kepulauan Bangka Belitung, 33172 Indonesia \\ Email: egytiansyah27@gmail.com
}

\begin{abstract}
ABSTRAK
Kepuasan merupakan salah satu faktor penting yang harus diperhatikan oleh seseorang agar dapat memuaskan konsumennya. Kualitas pelayanan mempunyai lima dimensi yang meliputi bukti langsung (tangibles), kehandalan (reliability), ketanggapan (reponsiveness), jaminan (assurance) dan empati (emphaty). Tujuan dari penelitian ini adalah untuk menganalisis tingkat kepuasan pengunjung terhadap pelayanan sarana transportasi Pulau Putri Kabupaten Bangka. Populasi penelitian ini adalah pengunjung Pulau Putri yang menggunakan jasa sarana transportasi penyebrangan, dengan jumlah sampel sebanyak 41 responden. Metode pengumpulan data yang digunakan adalah observasi dan wawancara. Metode wawancara menggunakan angket (kuesioner) yang ditanyakan kepada pengunjung Pulau Putri sebagai narasumber dari penelitian, sedangkan metode dokumentasi digunakan untuk mendokumentasi kegiatan penelitian. Analisis data yang digunakan yaitu analisis regresi linier berganda. Hasil penelitian menunjukkan kualitas pelayanan yang meliputi bukti langsung dan empati didapatkan nilai $Y=-0,98+0.56 X_{1}+0,48 X_{5}$. Berdasarkan hasil dari regresi linier berganda tersebut variabel bukti langsung $\left(X_{1}\right)$ dan variabel empati $\left(X_{5}\right)$ berpengaruh secara signifikan terhadap kepuasan pengunjung Pulau Putri Kabupaten Bangka.
\end{abstract}

Kata kunci : Kepuasan, Kualitas Pelayanan, Sarana Transportasi

\begin{abstract}
Satisfaction is one of the important factors that must be considered by someone in order to satisfy consumers. Service quality has five dimensions which include direct evidence (tangibles), reliability, responsiveness (responsiveness), assurance (assurance) and empathy (empathy). The purpose of this study was to analyze the level of visitor satisfaction with the transportation services of Pulau Putri, Bangka Regency. The population of this study were visitors at Putri island where used the services of crossing transportation, with a total sample of 41 respondents. The data collection methods used were observation and interviews. Interview using a questionnaire (questionnaire) which is asked to visitors to Putri island besides the documentation method. The data analysis used is multiple linear regression analysis. The results showed that the quality of service includes direct evidence, reliability, responsiveness, guarantee show the value of $Y=-0,98+0.56 X_{1}+0,48 X_{5}$ is obtained. Based on the results of the multiple linear regression, the direct evidence variable $\left(X_{1}\right)$ and the empathy variable $\left(X_{5}\right)$ have a significant effect on visitor satisfaction at Putri Island, Bangka Regency.
\end{abstract}

Keywords: Satisfaction, Service Quality, Means of Transportation

\section{PENDAHULUAN}

Kabupaten Bangka terletak pada $105^{\circ}$ sampai $106^{\circ}$ Bujur Timur dan 10 sampai $2^{\circ}$ Lintang Selatan. Berdasarkan posisi geografisnya, Bangka memiliki batas-batas: Utara berbatasan dengan Selat Karimata,
Selatan berbatasan dengan Kota Pangkalpinang dan Kabupaten Bangka Tengah, Barat berbatasan dengan Kabupaten Bangka Barat, Timur sampai Selat Karimata. Berdasarkan letak geografisnya, Kabupaten Bangka berada dekat dengan Pulau Sumatera (BPS Kabupaten Bangka, 2018). 
Pariwisata merupakan suatu produk yang dapat ditawarkan ke dalam pasar untuk diperhatikan, dimiliki, dipakai atau kebutuhan (Wijono, 2014). Karena pariwisata merupakan suatu produk, maka produk itu dapat dijual kepada konsumen, dalam hal ini adalah wisatawan yang berkunjung ke Pulau Putri. Pulau Putri adalah salah satu pulau yang sering dikunjungi di Pulau Bangka, tepatnya di Kabupaten Bangka. Lokasinya ada di Kecamatan Belinyu, daerah pesisir yang menakjubkan ini sangat popular baik untuk pengunjung domestik maupun mancanegara. Pulau Putri menawarkan air laut yang jernih dan suasana tenang. Perjalanan menuju Pulau Putri dapat ditempuh melalui jalur laut dari pantai penyusuk dengan sarana transportasi kapal menuju pulau tersebut dengan waktu tempuh sekitar 15 menit. Kepuasan merupakan salah satu faktor penting yang harus diperhatikan oleh seseorang agar dapat memuaskan konsumennya. Kepuasan konsumen menurut Kotler (2009) adalah perasaan senang atau kecewa seseorang yang berasal dari perbandingan antara kesannya terhadap kinerja suatu produk dan harapanharapannya. Kepuasan pelanggan menjadi tolak ukur bagaimana hal kedepannya, apa saja yang harus dirubah karena pelanggan merasa tidak puas.

Penelitian ini diambil untuk melihat seberapa besar pengaruh tingkat kualitas pelayanan yang di berikan dari kru tiap-tiap kapal terhadap penumpang. Dan faktorfaktor yang mempengaruhi kepuasan pengunjung terhadap sarana transportasi dan apa saja yang harus diperbaiki untuk meningkatkan kepuasan pengunjung tersebut. Kemudian permasalahan pada transportasi menuju Pulau Putri adalah belum adanya kajian kepuasan wisatawan terhadap transportasi pariwisata. Fasilitas transportasi laut yang dapat menunjang keamanan dan kenyamanan pengunjung, kesesuaian tarif dan kualitas pelayanan transportasi yang masih dapat dikatakan belum puas oleh sebagian pengunjung. Fasilitas yang semakin baik dari pihak pengelola dapat mempengaruhi kepuasan pelanggan yang berkunjung ke Pulau Putri. Tujuan penelitian ini adalah untuk menganalisis kepuasan pengunjung terhadap pelayanan sarana transportasi Pulau Putri Kabupaten Bangka.

\section{METODE PENELITIAN}

Waktu pelaksanaan penelitian ini yaitu pada bulan Februari 2020 dan tempat berlangsungnya penelitian ini yaitu di kawasan pesisir pantai Penyusuk dam juga di Pulau Putri Kecamatan Belinyu, Kabupaten Bangka.

Penentuan sampel responden menggunakan teknik purposive sampling. Penentuan jumlah sampel pada penelitian ini sesuai dengan jumlah populasi pengunjung Pulau Putri Kabupaten Bangka berjumlah 10.000 pada tahun 2019. Pengambilan sampel berdasarkan rumus (Fauzi, 2001):

$$
\mathrm{n}=\frac{N Z^{z}, 0,25}{\left[d^{z}(N-1)+\left[Z^{2}, 0,25\right]\right.}
$$

Keterangan: $\mathrm{n}=$ jumlah sampel yang diambil; $\mathrm{N}=$ jumlah populasi; 1 = kostanta; $0,25=$ kostanta; $\mathrm{d}^{2}=$ persen kelonggaran ketidaktelitian $(10 \%) ; \quad Z^{2}=$ tingkat kebenaran $(90 \%) .=$ jumlah sampel yang diambil = jumlah populasi (diketahui dan diperkirakan)

\section{Analisis Data}

Analisis yang digunakan dalam penelitian ini adalah analisis kuantitatif. Penelitian kuantitatif yaitu penelitian yang menekankan pada data-data numerikal (angka) yang diolah dengan metode statistika (Azwar, 2007).

\section{Analisis Regresi Linier Berganda}

Analisis regresi linear berganda digunakan untuk mengetahui hubungan sebab akibat dengan menentukan nilai $Y$ (sebagai variabel dependen) dan untuk menaksir nilai-nilai yang berhubungan dengan $X$ (sebagai variabel independen). Menurut Sugiyono (2014) persamaan regresi linier berganda yang ditetapkan adalah sebagai berikut:

$$
Y=b_{1} X_{1}+b_{2} X_{2}+b_{3} X_{3}+b_{4} X_{4}+b_{5} X_{5}
$$

Keterangan: $Y=$ kepuasan pengunjung; $X_{1}=$ bukti langsung; $X_{2}=$ kehandalan; $X_{3}=$ daya tanggap; $X_{4}=$ jaminan; $X_{5}=$ empati; $b_{1,2,3,4,5}$ $=$ keofisien regresi yang hendak diuji

\section{Uji Hipotesis}

Uji hipotesis dilakukan sebanyak $3 \mathrm{uji}$ dengan tujuan menganalisis keterkaitan antar variabel yang terdiri dari (1) Koefisien Determinasi $\left(R^{2}\right)$ : Koefisien determinasi adalah nilai yang digunakan untuk menunjukkan seberapa besar variabel bebas menjelaskan variabel terikat, $R^{2}$ rentan terhadap penambahan variabel bebas, dimana semakin banyak variabel bebas 
semakin besar nilai $\mathrm{R}^{2}$ (Agus, 2014). (2) Uji t (Uji Parsial): Menurut Suharyadi dan Purwanto (2009) uji parsial digunakan untuk menguji suatu variabel bebas berpengaruh nyata atau tidak terhadap variabel terikat. Pengujian dilakukan dengan menggunakan level signifikansi 0,05 $(a=5 \%)$ kriteria pengambilan keputusan: (a) Jika nilai thitung $>$ $t_{\text {tabel }}$ atau nilai signifikansi uji $t<0,05$ artinya variabel bebas secara parsial/individual berpengaruh terhadap kepuasan pengunjung. Jika nilai thitung $>$ ttabel atau nilai signifikansi uji $t<0,05$ artinya variabel bebas secara parsial / individual berpengaruh terhadap kepuasan pengunjung. (b) Jika nilai thitung $<$ ttabel atau nilai signifikansi uji t $>0,05$ artinya variabel bebas secara parsial/individual tidak berpengaruh terhadap kepuasan pengunjung. Jika nilai thitung < ttabel atau nilai signifikansi uji $t>0,005$ artinya variabel bebas secara parsial / individual tidak berpengaruh terhadap kepuasan pengunjung. (3) Uji $F$ (Uji Simultan): Menurut Suharyadi dan Purwanto (2009) uji statistika F pada dasarnya menunjukkan apakah semua variabel bebas mempunyai pengaruh secara simultan terhadap variabel terikat. Pengujian ini dilakukan dengan menggunakan level signifikansi $0,05 \quad(a=5 \%) \quad$ kriteria pengambilan keputusan: (a) Jika Fhitung < Ftabel atau nilai Signifikan $>0,05$ artinya variabel bebas secara bersama-sama tidak berpengaruh terhadap kepuasan pengunjung. Jika Fhitung < Ftabel atau nilai Signifikan > 0,05 artinya variabel bebas secara bersamasama tidak berpengaruh terhadap kepuasan pengunjung. (b) Jika nilai F $F_{\text {hitung }}>F_{\text {tabel }}$ signifikan $<0,05$ artinya variabel bebas secara bersama-sama berpengaruh terhadap kepuasan pengunjung.

\section{HASIL DAN PEMBAHASAN}

Tabel 1. Karakteristik Responden

\begin{tabular}{lcc}
\hline Karakteristik & Frekuensi & Presentase \\
\hline Umur & & \\
17-30 Tahun & 14 & $34,14 \%$ \\
31-45 Tahun & 11 & $26,82 \%$ \\
46-60 Tahun & 16 & $39,02 \%$ \\
Jenis Kelamin & & \\
Wanita & 29 & $70,73 \%$ \\
Laki-Laki & 12 & $29,26 \%$ \\
Pendidikan & & \\
Tidak Sekolah & 2 & $4,87 \%$ \\
SD & 9 & $21,95 \%$ \\
SMP & 4 & $9,75 \%$ \\
SMA & 21 & $31,21 \%$ \\
\hline
\end{tabular}

\begin{tabular}{lcc}
\hline Karakteristik & Frekuensi & Presentase \\
\hline SMK & 1 & $2,43 \%$ \\
D3 & 1 & $2,43 \%$ \\
S1 & 3 & $7,31 \%$ \\
Pekerjaan & & \\
Wiraswasta & 9 & $21,95 \%$ \\
IRT & 15 & $36,58 \%$ \\
WIrausaha & 2 & $4,87 \%$ \\
PNS & 3 & $7,31 \%$ \\
Pelajar & 3 & $7,31 \%$ \\
Mahasiswa & 6 & $14,63 \%$ \\
Buruh Harian & 1 & $2,43 \%$ \\
Pesiunan & 1 & $2,43 \%$ \\
\hline
\end{tabular}

\section{Kunjungan Responden}

Tabel 2. Kunjungan Responden

\begin{tabular}{lcc}
\hline Kunjungan & Frekuensi & Presentase \\
\hline Jumlah & & \\
$1 x$ & 20 & $49 \%$ \\
$2 x$ & 12 & $29 \%$ \\
$3 x$ & 4 & $10 \%$ \\
$5 x$ & 1 & $3 \%$ \\
$7 x$ & 2 & $5 \%$ \\
$10 x$ & 1 & $2 \%$ \\
$32 x$ & 1 & $2 \%$
\end{tabular}

Tujuan

rekreasi

berdagang $\quad 40 \quad 98 \%$

Rekan $11 \%$

Sendiri $\quad 1 \quad 3 \%$

Keluarga $\quad 19 \quad 46 \%$

teman $21 \quad 51 \%$

\begin{tabular}{lcc} 
Biaya Kapal & & \\
Rp 25.000 & 36 & $88 \%$ \\
Rp 300.000 & 5 & $12 \%$ \\
\hline
\end{tabular}

\section{Analisis Faktor yang Mempengaruhi Kepuasan Pengunjung}

Faktor-faktor yang mempengaruhi kepuasan pengunjung di analisis menggunakan uji regresi berganda dengan tujuan melihat sebuah variabel berpengaruh atau tidak pada tingkat kepuasan pengunjung. Hasil analisis menunjukkan model regresi yaitu $Y=-0,98$ $+0,56 X_{1}+0,48 X_{5}$.

Tabel 3. Analisis Regresi Linier Berganda

\begin{tabular}{cc}
\hline Model & Nilai B \\
\hline Nilai Konstan & $-0,98$ \\
Bukti Langsung $\left(X_{1}\right)$ & 0,56 \\
Empati $\left(X_{5}\right)$ & 0,48 \\
\hline
\end{tabular}


Uji $R^{2} \quad$ (koefisien determinasi) menunjukkan bahwa nilai adjusted $\mathrm{R}^{2}$ sebesar 0,732 atau $73,2 \%$. Hal ini menunjukkan bahwa kepuasan pengunjung dapat dijelaskan sebesar $73,2 \%$ oleh variabel independen yaitu bukti langsung dan empati. Sedangkan $26,8 \%$ kepuasan pengunjung dapat dijelaskan oleh variabel-variabel diluar variabel independen penelitian ini.

Tabel 4. Uji Koefisien Determinasi $\left(R^{2}\right)$

\begin{tabular}{cccc}
\hline Model & $\mathrm{R}$ & $\begin{array}{c}R \\
\text { Square }\end{array}$ & $\begin{array}{c}\text { Adjusted } \\
R \text { Square }\end{array}$ \\
\hline 1 & $0,863^{\mathrm{a}}$ & 0,745 & 0,732 \\
\hline
\end{tabular}

Berikut ini adalah hasil dari pengujian secara parsial:

Tabel 5. Uji Secara Parsial

\begin{tabular}{lccl}
\hline Model & Nilai t & Nilai tabel & $\begin{array}{l}P \text { - } \\
\text { Value }\end{array}$ \\
\hline Bukti & 4,481 & 1,685 & 0,000 \\
Langsung $\left(X_{1}\right)$ & & & \\
Empati $\left(X_{5}\right)$ & 4,166 & 1,685 & 0,000 \\
\hline
\end{tabular}

Berdasarkan pengujian hipotesis

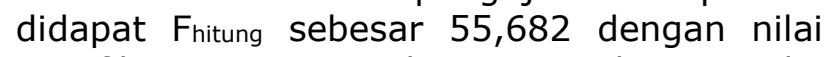
signifikansi $0,000<$ dari 0,05 sehingga nilai Fhitung yang diperoleh tersebut signifikan yang menyatakan adanya pengaruh tangibles (bukti langsung) dan emphaty (empati) secara bersama-sama terhadap kepuasan pengunjung pada sarana transportasi Pulau Putri Kabupaten Bangka.

Tabel 6. Uji Secara Simultan

\begin{tabular}{llc}
\hline Model & Fhitung & Nilai Sig \\
\hline Regression & 55,682 & 0,000 \\
\hline
\end{tabular}

\section{Karakteristik Responden}

Hasil penelitian ini menunjukkan bahwa usia pengunjung di Pulau putri paling banyak terdapat pada umur 46-60 tahun, pada kelompok usia 46-60 tahun adalah kelompok usia yang masih produktif dengan kesehatan yang masih bagus untuk melakukan perjalanan (Koranti et al, 2018). Jenis kelamin merupakan pembagian dua jenis kelamin (penyifatan) manusia yang ditentukan secara biologis yang melekat pada jenis kelamin tertentu (Fakih, 2008). Pengunjung Pulau Putri memiliki jenis kelamin yang berbeda-beda pada setiap orangnya. Pengunjung dalam penelitian ini juga paling banyak berjenis kelamin perempuan. Pengunjung perempuan umumnya lebih suka berwisata. Hal ini sesuai dengan Wijono (2014), yang mengatakan bahwa perempuan lebih suka berwisata.

Menurut Nata (2001), pendidikan adalah bimbingan atau arahan secara sadar oleh si pendidik terhadap perkembangan jasmani dan rohani terdidik menuju terbentuknya kepribadian yang utama. Karakteristik pengunjung berdasarkan tingkat pendidikan di Pulau Putri didominasi oleh pengunjung yang berpendidikan SMA dengan jumlah 21 pengunjung. Latar belakang pendidikan pengunjung berpengaruh terhadap pemahaman seseorang terhadap rasa ingin tahu seseorang tentang objek wisata dibandingkan dengan pendidikannya yang lebih rendah dan pendidikan tinggi juga akan memperhatikan aktivitas kegiatan pelayanan dan kualitas fasilitas yang diberikan (Modjanggo et al., 2015).

Pekerjaan secara umum di definisikan sebagai sebuah kegiatan aktif yag dilakukan oleh manusia. Manusia selalu melakukan bermacam-macam aktivitas, salah satu wujud dari aktivitas itu adalah kerja atau bekerja. Karakteristik pengunjung berdasarkan pengunjung terbanyak merupakan ibu rumah tangga hal ini sesuai dengan kelompok usia sebelumnya bahwa kelompok umur pengunjung 46-60 tahun. Ibu rumah tangga dengan umur yang masih produktif dengan mereka yang masih penuh energi dan cenderung akan mencari pengalaman wisata bersama keluarga maupun dengan keluarganya (Koranti et al, 2018).

\section{Kunjungan Responden}

Jumlah kunjungan sangat berpengaruh bagi pendapatan warga sekitar. Rantetadung (2012) menyatakan bahwa pengaruh kunjungan wisatawan sangat berarti untuk pengembangan industri pariwisata dan pendapatan asli daerah sehingga wisatawan domestik maupun wisatawan mancanegara tertarik untuk berkunjung. Wisatawan adalah orang yang memiliki waktu luang sementara dan sengaja mengunjungi suatu tempat yang jauh dari rumahnya, dengan tujuan untuk mencari pengalaman baru yang tidak ditemukan dalam kegiatannya sehari-hari (Wijono, 2014). Wisatawan atau pengunjung yang berkunjung ke Pulau Putri dalam waktu 1 tahun terakhir memiliki jumlah kunjungan yang berbeda-beda. Untuk yang berkunjung 1 kali sebanyak 20 orang, berkunjung 2 kali sebanyak 12 orang, berkunjung 3 kali sebanyak 4 orang, berkunjug 5 kali sebanyak 
1 orang, berkunjung 7 kali sebanyak 2 orang, berkunjung 10 kali sebanyak 1 orang, dan yang berkunjung 32 kali sebanyak 1 orang.

Pengunjung yang berkunjung ke Pulau Putri didominasi oleh pengunjung yang bertujuan untuk rekreasi dan untuk menghibur yang dilakukan diluar kegiatan sehari-hari yang dilakukan guna untuk memberikan keuntungan yang bersifat permanen ataupun sementara. Jumah pengunjung yang bertujuan untuk rekreasi sebanyak 40 orang pengunjung (98\%) dan untuk pengunjung yang bertujuan untuk berdagang atau berjualan di Pulau Putri hanya 1 orang ( $2 \%)$ saja.

Pengunjung memilih rekan berkunjung berwisata ke Pulau Putri yang berbeda-beda pada setiap oranynya. Pengunjung yang berpergian sendiri sebanyak 1 orang (3\%) yaitu orang yang berdagang di Pulau Putri, untuk yang berpergian bersama keluarga sebanyak 19 orang (46\%) dan yang berpergian bersama teman-temannya sebanyak 21 orang (51\%). Pengunjung lebih dominan bepergian bersama temantemannya.

Salah satu hal yang menjadi pertimbangan pengunjung dalam berwisata adalah biaya. Menurut Mulyadi (2008), pengertian biaya adalah penggunaan sumber-sumber ekonomi yang diukur dengan satuan uang, yang telah terjadi atau kemungkinan akan terjadi untuk objek atau tujuan tertentu. Biaya dapat diklasifikasikan berdasarkan dapat atau tidaknya biaya tersebut diidentifikasikan terhadap objek biaya. Objek biaya yang dimaksud adalah produk, jasa, fasilitas dan lain-lain. Biaya Kapal untuk berangkat dari pantai Penyusuk ke Pulau Putri untuk harga normal Rp.25.000 sebanyak 36 orang $(88 \%)$, dan untuk harga rombongan Rp.300.000 sebanyak 5 orang $(12 \%)$.

\section{Analisis Faktor yang Mempengaruhi Kepuasan Pengunjung}

Penelitian ini memiliki 5 variabel yang terdiri dari bukti langsung $\left(X_{1}\right)$, kehandalan $\left(X_{2}\right)$, daya tangkap $\left(X_{3}\right)$, jaminan $\left(X_{4}\right)$ dan empati $\left(X_{5}\right)$, setelah dilakukan eleminir, variabel yang tersisa memiliki dua variabel yang menjadi variabel independen yang berpengaruh seraca signifikan yaitu variabel bukti langsung dan empati. Eliminir dilakukan dikarenakan nilai signifkansi pada tiga variabel yang dieleminir terlalu tinggi sehingga pada perhitungan menunjukkan bahwa variabel tersebut tidak berpengaruh karena nilai signifikansi untuk tiga variabel (kehandalan sebagai $X_{2}$, daya tangkap sebagai $X_{3}$ dan jaminan sebagai $X_{4}$ ) melebihi nilai 0,05 . Hal ini sesuai dengan Suharyadi dan Purwanto (2009) yang mengatakan bahwa apabila signifikansi lebih besar dari 0,05 artinya variabel tersebut tidak berpengaruh terhadap kepuasan pegunjung sehingga hanya ditampilkan dua variabel yang berpengaruh yaitu bukti fisik $\left(X_{1}\right)$ dan empati $\left(X_{5}\right)$.

Bukti Fisik (Tangible) yaitu berkenaan dengan daya tarik fasilitas fisik, perala. Tangibles (berwujud), yaitu kemampuan pengelola objek wisata dalam menunjukkan eksistensinya kepada pelanggan (Rad, 2010). Dimensi ini meliputi fasilitas fisik seperti sarana dan prasarana yang disediakan oleh pengelola objek wisata, peralatan yang digunakan, serta penampilan karyawan (Bucak, 2014). Hasil dari uji t variabel menunjukkan bukti langsung mempunyai $t_{\text {hitung }}$ sebesar 4,481 dan nilai tabel sebesar 1,685 dengan nilai $p$-value 0,000 lebih kecil dari 0,05. Dilihat dari nilai kepuasan pengunjung didapatkan nilai sebesar 0,56 yang menunjukkan adanya peningkatan kepuasan pengunjung sebesar $5,6 \%$ dari $100 \%$ jumlah responden, berarti variabel bukti langsung berpengaruh positif dan signifikansi terhadap kepuasan pengunjung dan menyatakan tangibles (bukti langsung) pada kepuasan pengunjung yang menggunakan sarana transportasi ke Pulau Putri ini dikategorikan puas dengan fasilitas fisik dan penampilan pekerja yang baik sehingga pengunjung merasa puas dengan fasilitas yang disediakan tersebut.

Empati (Empathy) menyatakn bahwa

perusahaan memahami masalah para konsumennya dan bertindak demi kepentingan konsumen, serta memberikan perhatian personal kepada para konsumen dan memiliki jam operasi yang nyaman (Tjiptono et al., 2011). Pemberian perhatian secara individual, pemahaman yang lebih baik mengenai kebutuhan spesifik pengunjung, peningkatan komunikasi antara manajemen dan pelanggan akan berpengaruh secara positif pada kepuasan pelanggan (Ananth et al., 2011). Dari hasil $u j i$, variabel empati mempunyai thitung sebesar 4,166 dan nilai tabel sebesar 1,685 dengan nilai $p$-value 0,000 lebih kecil dari 0,05 yang berarti bahwa variabel empati berpengaruh positif dan signifikansi terhadap kepuasan pengunjung. Kemudian dilihat dari nilai kepuasan pengunjung didapatkan nilai sebesar 0,48 yang menunjukkan adanya 
peningkatan kepuasan pengunjung sebesar $4,8 \%$ dari $100 \%$ jumlah responden. Dalam dimensi ini, kru kapal perlu mengetahui keinginan pengunjung, paham akan kebutuhannya, serta mampu membuat wisatawan merasa nyaman.

Pemberian layanan yang lebih baik dibandingkan pesaing akan mempengaruhi tingkat kepuasan wisatawan. Dalam penerapan aspek emphaty (empati), kru kapal lebih memfokuskan pada pemaham kru kapal kepada penumpang, kru tidak pilih kasih kepada penumpang, kemudahan dalam memesan kapal, menggunakan bahasa yang mudah dipahami, dan kemudahan penumpang menjadi pelanggan kapal tersebut. Ini berarti peningkatan kepuasan pengunjung pada variabel ini diakibatkan oleh kru kapal yang selalu memahami kebutuhan penumpang, kru kapal tidak pilih kasih dalam melayani semua penumpangnya, kemudaham para pengunjung untuk memesan kapal yang sama menggunakan alat komunikasi, kru kapal menggunakan bahasa yang mudah dimengerti oleh semua penumpang pada waktu bepergian maka akan terciptanya komunikasi yang baik akan memberikan informasi kepada kru kapal sehingga memahami kebutuhan pengunjung sehingga menciptakan kepuasan pengunjung.

\section{KESIMPULAN}

Kepuasan pengunjung terhadap sarana transportasi di Pulau Putri Kabupaten Bangka memiliki persamaan $Y=-0,98+0,56 X_{1}+$ $0,48 X_{5}$ yang menunjukkan bahwa variabel bukti langsung $\left(X_{1}\right)$ dan empati $\left(X_{5}\right)$ berpegaruh secara signifikan terhadap kepuasan pengunjung yang mengunjungi Pulau Putri dengan menggunakan sarana transportasi perahu di kawasan wisata Pantai Penyusuk, Belinyu.

\section{REFERENSI}

Nata, A. 2001. Pemikiran Para Tokoh Pendidikan Islam, Jakarta: PT. Rineka Cipta.

Agus T.B. 2014. Penggunaan SPSS Dalam Statistik. Yogyakarta: Danisa Media.

Ananth, A., Ramesh, R., \& Prabaharan, B. 2011. Service Quality GAP Analysis in
Private Sector Banks A Customer Perspective. Indian Journal of Commerce \& Management Studies, 2 (1):245-252.

Azwar, S. 2007. Metode Penelitian. Pustaka Pelajar: Yogyakarta.

Bucak, T. 2014. The Effect of Service Quality on Customer Satisfaction: A Research on Hotel Businesses, International Journal of Education and Research, 2 (1): 1-12.

BPS (Badan Pusat Statistik) Provinsi Kepulauan Bangka Belitung, 2018. Kabupaten Bangka Dalam Angka 2012. Pangkalpinang: Badan Pusat Statistik Provinsi Kepulauan Bangka Belitung.

Fauzi A. 2001. An Economic Analysis of the Surplus Production and Aplication For Indonesian Small Pelagic Fishery. Journal Institut Pertanian Bogor, 2(1):135-138.

Koranti, K., Sriyanto, S. \& Lestiyono, S. 2018. Analisis Preferensi Wisatawan terhadap Sarana di Wisata Taman Wisata Kopeng. Jurnal IImiah Ekonomi Bisnis, 22(3):242:254

Kotler, K. 2009. Manajemen Pemasaran 1. Edisi ketiga belas. Jakarta: Erlangga.

Modjanggo, F., Sudhartono, A. \& Sustri, S. 2015. Faktor - Faktor yang Mempengaruhi Jumlah Pengunjung Ke Objek Ekowisata Pantai Siuri, Desa Toinasa Kecamatan Pamona Barat Kabupaten Poso. Jurnal Warta Rimba, 3(2):88-95

Mulyadi. 2008. Sistem Akuntansi. Jakarta: Salemba Empat.

Sugiyono. 2014. Metode Penelitian Kuantitatif, Kualitatif, dan Kombinasi (Mixed Methods). Alfabeta: Bandung.

Suharyadi \& Purwanto S. K. 2009. Statistika: Untuk Ekonomi dan Keuangan Modern.Jakarta: Salemba empat.

Tjiptono, Fandy \& Gregorius Chandra. 2011. Service Quality \& Satisfaction Edisi ketiga. Yogyakarta: Andi Offset.

Wijono, D. 2014. Tingkat Kepuasan Pengunjung Obyek Wisata Pantai Kuwaru Sanden Bantul Yogyakarta. Jurnal Maksipreneur: Manajemen, Koperasi, dan Entrepreneurship, 4(1):22-35. 